This is the final peer-reviewed accepted manuscript of:

Long INterspersed nuclear Elements (LINEs) in brain and non-brain tissues of the rat. Giorgi G, Virgili M, Monti B, Del Re B.

The final published version is available online at:

https://doi.org/10.1007/s00441-018-2843-9

Rights / License:

The terms and conditions for the reuse of this version of the manuscript are specified in the publishing policy. For all terms of use and more information see the publisher's website.

This item was downloaded from IRIS Università di Bologna (https://cris.unibo.it/)

When citing, please refer to the published version. 


\title{
Long INterspersed nuclear Elements (LINEs) in brain and non-brain tissues of the rat
}

\author{
Gianfranco Giorgi $^{1} \cdot$ Marco Virgili $^{1} \cdot$ Barbara Monti $^{1} \cdot$ Brunella Del Re ${ }^{1}$
}

Received: 7 August 2017 / Accepted: 11 April 2018

(C) Springer-Verlag GmbH Germany, part of Springer Nature 2018

\begin{abstract}
Long INterspersed Element-1 (L1) is a transposable element that can insert copies of itself in new genomic locations causing genomic instability. In somatic cells, L1 retrotransposition activity is usually repressed but somatic L1 retrotransposition has recently been observed during neuronal differentiation. In this study, we evaluate whether L1 elements are differentially active in rat tissues during postnatal development. To this purpose, we quantified L1 in genomic DNA extracted from the olfactory bulb $(\mathrm{OB})$, cerebellum $(\mathrm{CE})$, cortex $(\mathrm{CO})$ and heart $(\mathrm{H})$. Each analysis was repeated on rats aged 7, 21 and 60 days. We found that L1 content in $\mathrm{OB}$ and $\mathrm{CE}$ tissue was significantly higher than $\mathrm{H}$ tissue, in rats of all three ages studied, suggesting that $\mathrm{L} 1$ activity could be modulated in postnatal development and neurogenesis.
\end{abstract}

Keywords LINE-1 $\cdot$ Retrotransposition $\cdot$ Rat $\cdot$ Brain $\cdot$ Development

\section{Introduction}

Long INterspersed Element-1 (LINE-1 or L1) is a non-long terminal repeat (LTR) autonomous retrotransposon, which constitutes approximately 17,20 and $23 \%$ of human, mouse and rat genomes respectively. Fully functional L1s insert copies of themselves into new genomic locations via retrotransposition, which involves L1 reverse transcription and integration by the target-primed reverse transcription mechanism (TPRT) (Feng et al. 1996). L1 retrotransposition may cause genomic instability, genetic disorders and cancers through insertional mutagenesis; further, it is a major force in shaping the structure and function of mammalian genomes (Boissinot and Sookdeo 2016).

Gianfranco Giorgi and Marco Virgili are co-first authors.

Electronic supplementary material The online version of this article (https://doi.org/10.1007/s00441-018-2843-9) contains supplementary material, which is available to authorized users.

Brunella Del Re

brunella.delre@unibo.it

1 Department of Pharmacy and Biotechnology (FaBiT), University of Bologna, via Selmi 3, 40126 Bologna, Italy
The full-length mammalian $\mathrm{L} 1$ is about $6 \mathrm{~kb}$ and is made up of a $5^{\prime}$ untranslated region ( $5^{\prime}$ UTR) with internal sense and antisense RNA polymerase II promoters, open reading frame ORF1 and ORF2, encoding proteins involved in retrotransposition and a $3^{\prime}$ untranslated region ( $3^{\prime}$ UTR) with a polyadenylation site (Ostertag and Kazazian 2001). Recently, an additional ORF (ORF0), in the antisense 5' UTR of L1, was reported in primate lineage, which might play some positive regulatory role in the retrotransposition process (Denli et al. 2015). However, most of the L1 sequences present in mammalian genomes are retrotransposition defective due to $5^{\prime}$ truncation and mutations in ORF2 (Kazazian 2004); in the human genome, approximately 80 to $100 \mathrm{~L} 1 \mathrm{~s}$ remain retrotransposition competent (Brouha et al. 2003).

L1 activity is usually repressed in somatic cells by various host defense mechanisms (reviewed recently by Goodier 2016), which are often impaired in cancer cells (Iskow et al. 2010) and can be affected by environmental stress (Del Re et al. 2012; Del Re and Giorgi 2013; Miousse et al. 2015). Until recently, L1 retrotransposition was thought to occur only in germ cells and in tumor cells. This hypothesis changed when several reports showed that L1 mobilization can occur in mouse and human brains. Muotri et al. (2005) showed that an engineered human LINE-1 element could retrotranspose in rat neural precursor cells (NPC) in vitro and in transgenic 
mouse brain in vivo. Coufal et al. (2009) reported that the copy number of endogenous L1s in several regions of adult human postmortem brains was higher than that detected in heart or liver genomic DNAs from the same donor. Other papers reported that somatic endogenous L1 retrotranspositions occur in the human hippocampus, caudate nucleus and cerebral cortex (Baillie et al. 2011; Evrony et al. 2012; Kurnosov et al. 2015; Upton et al. 2015). Moreover, it has been observed that endogenous LINE-1 insertions in human brain preferentially affect genes involved in neuronal functions (Baillie et al. 2011; Upton et al. 2015). Other observations indicated that transposable elements are active in the Drosophila brain (Li et al. 2013), suggesting that mobile element activity is not restricted to the mammalian brain. Therefore, it is now accepted that L1 elements are mainly active in neural progenitors, although the debate is still open about the rate of L1 insertions per neuron (Evrony et al. 2012; Evrony et al. 2016; Upton et al. 2015; Goodier 2016, b; Faulkner and Garcia-Perez 2017). A recent report (Macia et al. 2017) indicates that $\mathrm{L} 1$ retrotransposition can also take place in non-dividing mature neuronal cells.

On the basis of these reports, L1 may contribute to both neuronal plasticity and neurological functions (Erwin et al. 2014). An open question is if L1 activity plays a role in some neuropathological conditions and if so, how. Some evidence has emerged recently about L1 activity's role in neurological disease, such as Rett syndrome and posttraumatic stress disorder (PTSD) and in psychiatric disorders, such as depression and bipolarism (Baillie et al. 2011; Bundo et al. 2014; Guffanti et al. 2016; Liu et al. 2016).

Since the rat is still one of the most important model systems for human neurological and psychiatric disorders (Abbott 2004; Cohen et al. 2003), it may be useful to obtain information about L1 retrotransposition in rat neural tissues. Indeed, until now, L1 activity has been studied mainly through the use of human and mouse cells and tissues, with the exception of Muotri et al. (2005) who showed that human L1 elements could retrotranspose in rat neural precursor cells. L1 of rat (Rattus norvegicus) is the most successful mammalian L1 retrotransposon identified so far, constituting around 23\% in the rat genomes (Gibbs et al. 2004). The basic structure of the reported full-length rat $\mathrm{L} 1\left(\mathrm{RnL} 1\right.$ accession $\mathrm{n}^{\circ}$ DQ100473) is similar to that of human L1 except for the $5^{\prime}$ UTR, which is bipartite and consists in tandem arrays of monomers (about $650 \mathrm{bp}$ ) connected to ORF1 by a specific tether sequence (Furano 2000; Kirilyuk et al. 2008).

The aim of this work is to assess L1 retrotransposition in different rat brain tissues evaluating variation of $\mathrm{L} 1$ content by comparison of age-related differences and tissue-related differences. Three postnatal development stages $(7,21,60$ days of age) were investigated. Three tissues (olfactory bulb, cortex and cerebellum) and a non-neural control tissue (heart) were analyzed.

\section{Materials and methods}

\section{Tissue specimens}

Tissues were dissected from Wistar rat (Harlan Italy, Udine, IT). Animals were maintained on a 12:12-h light/dark cycle and given food and water ad libitum. All animal experiments were authorized by a local bioethical committee (Protocol $\mathrm{n}^{\circ}$ 17-72-1212) and performed according to the Italian and European Community laws on animal use for experimental purposes. Olfactory bulb (BO), cerebellum (CR), cortex (CX) and heart (Cuo) were collected and stored at $-80{ }^{\circ} \mathrm{C}$ until processed for DNA extraction. All the tissues were from rats at $7(n=7), 21(n=5)$ and $60(n=9)$ days of age.

\section{DNA extraction and real-time PCR analysis}

Tissue sample of about $20 \mathrm{mg}$ was finely minced and incubated with $500 \mu \mathrm{l}$ of lysis solution $(10 \mathrm{mM}$ Tris- $\mathrm{HCl} \mathrm{pH} 8.0$, $1 \mathrm{mM}$ EDTA, $1.5 \%$ SDS, $200 \mu \mathrm{g}$ proteinase $\mathrm{K}$ ) overnight at $56{ }^{\circ} \mathrm{C}$. DNA genomic was extracted and purified with QIAamp® DNA Micro kit (QIAgen, Hilden, Germany) according to the manufacturer's instructions.

Real-time PCR was performed using multiplex TaqMan qPCR assay. TaqMan ${ }^{\circledR}$ Universal Master Mix II with Uracil-N glycosylase (UNG) (Applied Biosystems, Foster City, CA, USA) and a probe with VIC (4,7,2'-trichloro-7'phynil-6-carboxyfluorescein) or FAM (6-carboxyfluorescein) reporter were used. Oligonucleotide PCR primers and TaqMan-MGB probes were designed by qPCR Assay design by IDT (Integrated DNA Technologies) and purchased from Applied Biosystems. The following primers and probe were used at $300 \mu \mathrm{M}$ final concentration: ORF2-1 sequence: GAGTGTTCCTCTTTCTCCACAACCT (forward), GTGCGATTGGCTAAGATC (reverse), CCACAACC TCGCCAGCATCT (probe); ORF2-2 sequence: TGCAGATCGATCCATGCTTATC (forward), GTTCCAGA TGCTTCCCTAGTTT (reverse), ACCTCCACATCAAA CCAGACACACT (probe).

The following primers and probe were used at $150 \mu \mathrm{M}$ final concentration: 5' UTR L1 sequence: AAGAACAG CTGAAGACCTGTAG (forward), CTATAAGCCTGTGT GTCAGGAG (reverse), AACTACACGCCGGAAAGCAG AACA (probe).

The following primers and probe were used at $720 \mu \mathrm{M}$ final concentration: 5S Rib gene: GCCATACCACCCTG AAC (forward), GGTCTC CCATCCAAGTAC (reverse), TCG TCT GAT CTC GGA AGC TAA GC (probe).

ORF2-1 and ORF2-2 probes were conjugated to the fluorophore label VIC and all other probes were conjugated with 6-FAM. For the control assay depicted in Fig. 3 (5' UTR/5S RNA), the 5' UTR probe was generated with the VIC fluorophore in order to multiplex with the 5S Rib-6-FAM probe. 
Copy numbers were determined using the UCSC rat genome, assembly July 2014, browser in silico PCR function. ORF2-1 matches 200 genomic L1s; ORF2-2 matches 8200 genomic L1s; 5' UTR matches 8500 genomic L1s; 5S Rib matches 17 ribosomal genes.

Amplicons were verified using the L1Base2 (http://11base. charite.de/11base.php) and matched a minimum of 500 rat fulllength LINE-1 elements in the database with the following identities: $98 \%$ identities, E value 2e-33 (ORF2-1); $99 \%$ identities, E value 2e-62 (ORF2-2); 98\% identities, E value 2e-58 (5' UTR).

Each sample was routinely analyzed in triplicate.

Quantitative PCR experiments were performed using a StepOne Real-Time PCR Detection System (Applied Biosystems, Foster City, CA, USA) according to standard protocol. Data shown in figures were additionally normalized to the lowest value shown as 1.0 , as previously described by Coufal et al. (2009).

\section{Rat sex determination}

The genotypic sex of each animal was identified from the presence (male) or the absence (female) of SRY gene by PCR using PCR Ready Mix (Sigma, Milan, Italy).

As a control, a sequence of beta-actin gene (ACTB, Chr. 12p11) was also amplified. Therefore, PCR of SRY sequence yielded a $317 \mathrm{bp}$ product in the male samples but not in the female ones. PCR of ACTB sequence yielded a 228 bp product in all the samples, confirming successful PCR. Female and male tissues were used as reference.

The following primers were used to amplify the SRY sequence: TACAGCCTGAGGACATATTA (forward), GCACTTTAACCCTTCGATGA (reverse). The following primers were used to amplify the ACTB sequence: AGCCATGTACGTAGCCATCC (forward), CTCTCAGC TGTGGTGGTGAA (reverse).
Fig. 1 L1 content in tissues of rat 7, 21 and 60 days of age. ORF2-1 primers and probe were used with 5S Rib gene as an internal control. Values were standardized such that the lowest value of all the experiments (heart tissue from a 7-day-old rat) was normalized to 1.0. Means and standard errors are shown. OB, olfactory bulb; $\mathrm{CO}$, cortex; $\mathrm{CE}$, cerebellum; $\mathrm{H}$, heart. Number (7, 21 and 60) is for days of age. Data are grouped by age group (a) and by tissue type (b). All one-way ANOVA analyses, both between tissues within each age group (a) and between age groups within each tissue (b), were significant (respectively $p<0.002$ and $p<0.01)$. Tukey HSD test and Bonferroni tests were applied, significant differences are shown. (*) $p<0.05 ;(* *) p<0.01$ a

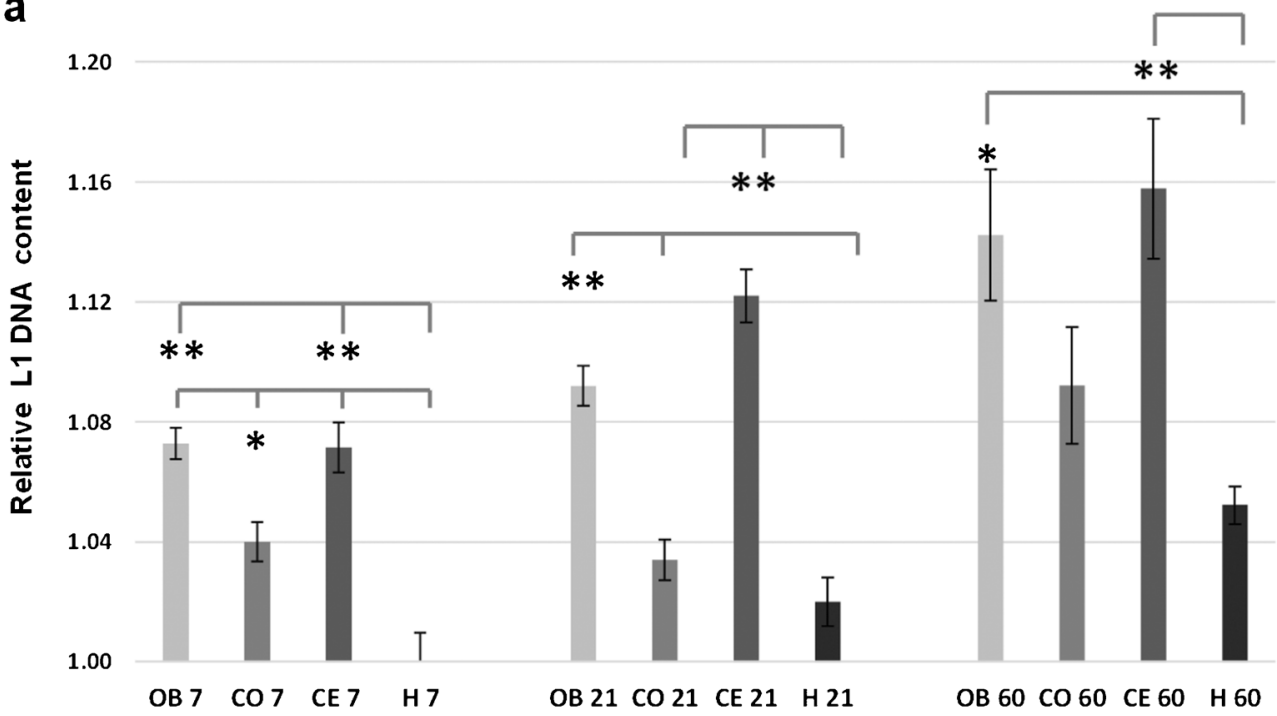

b

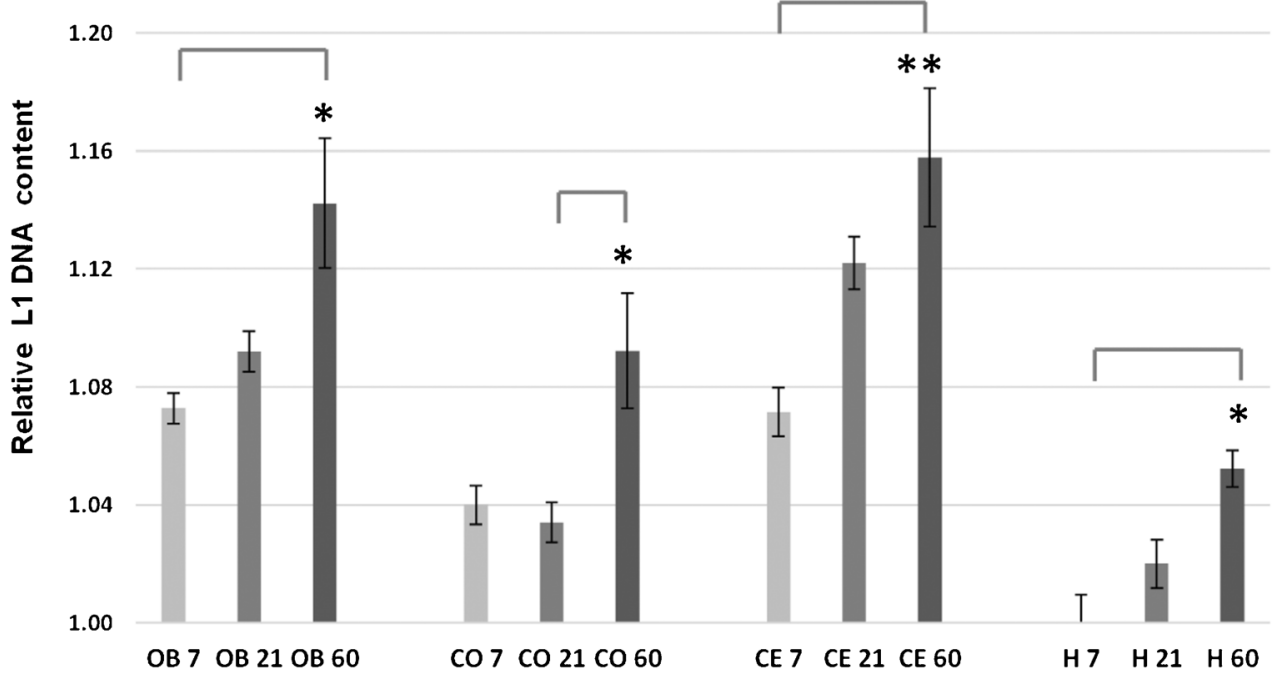




\section{Statistical analyses}

One-way analysis of variance (ANOVA) both between tissues within each age group and between age groups within each tissue, was applied and when it resulted significant $(p<0.05)$, Tukey HSD test and Bonferroni and Holm tests were used.

Comparison between male and female was performed by $t$ Student test.

\section{Results and discussion}

To investigate whether L1 elements are differentially active in various tissues at early stages of postnatal development, we studied tissues of 21 rats from 7 to 60 days of age. Olfactory bulb (OB), cerebellum (CE), cortex (CO) and heart $(\mathrm{H})$ tissue samples were collected from each rat. Genomic DNA was extracted from each sample and analyzed for L1 content by multiplex TaqMan qPCR assay.

Figure 1 shows the L1 content, evaluated through analysis of ORF2-1 sequences, in $\mathrm{OB}, \mathrm{CO}, \mathrm{CE}$ and $\mathrm{H}$ tissues of rats of 7,21 and 60 days of age (individual data are reported in Electronic Supplementary Material, Table S1). Figure 1a shows that L1 content in OB and CE tissues was higher than in $\mathrm{H}$ tissues, in rats of all three ages. These results are congruent with the data obtained by Coufal et al. (2009) studying human tissues. Indeed, they found an increase in the L1 content in several regions of adult human brains, when compared to the copy number of endogenous L1s in the heart or liver. The significant L1 increase observed in $\mathrm{OB}$ tissue may be related to neurogenesis, according to Muotri et al. (2005). It is well known that $\mathrm{OB}$ is a site of postnatal and adult neurogenesis (Altman 1962; Altman 1969), as well as the forebrain sub-ventricular zone (Wagner et al. 1999;
Fig. 2 Multiplex qRT-PCR analysis of tissues of rat of 7,21 and 60 days of age using $5^{\prime}$ UTR $\mathrm{L} 1$ primers and a probe with $5 \mathrm{~S}$ Rib gene as internal control. Values were standardized such that the lowest value of all the experiments (heart tissue from a 21-day-old rat) was normalized to 1.0. Means and standard errors are shown. OB, olfactory bulb; CO, cortex; $\mathrm{CE}$, cerebellum; $\mathrm{H}$, heart. Number $(7,21$ and 60$)$ is for days of age. Data are grouped by age group (a) and by tissue type (b). One-way ANOVA analysis both between tissues within each age group was not significant except for the 60 age group $(p<0.05)$ (a). One-way ANOVA analysis between age groups within each tissue was not significant (b). Tukey HSD test and Bonferroni tests were applied, significant difference is shown. $(*) p<0.05$ a

1.20

1.16

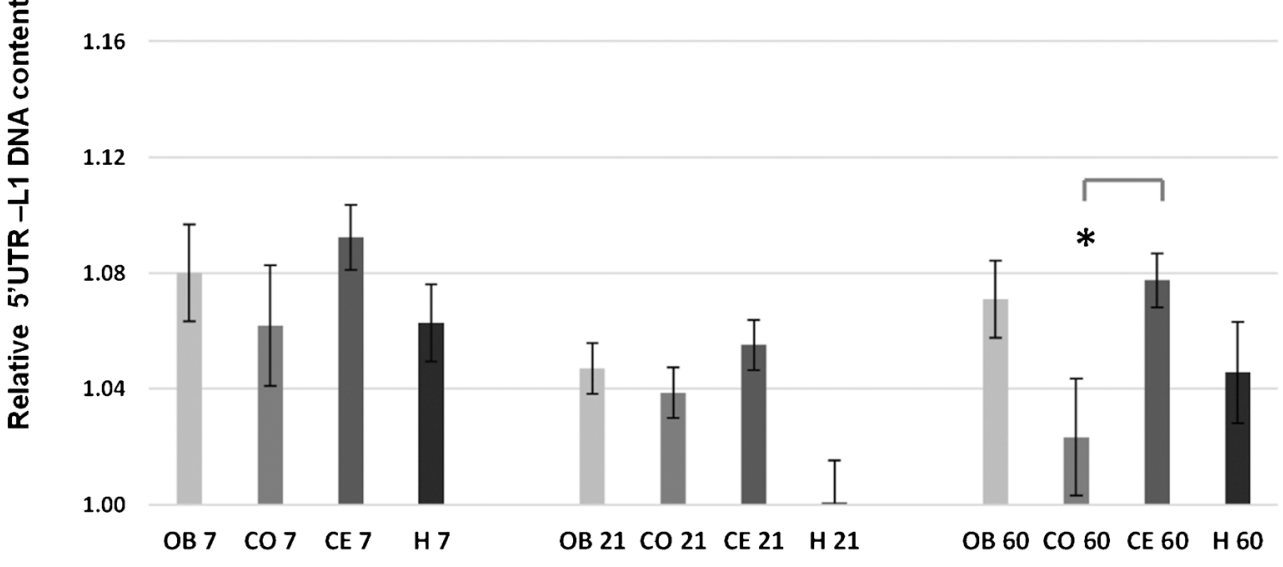

b

1.20

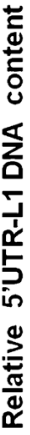

1.16

1.12

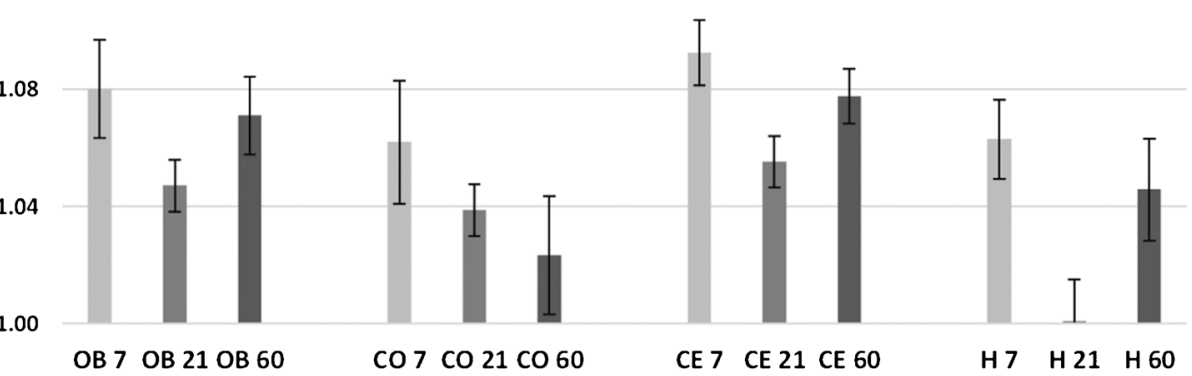


Levison et al. 1999). The L1 increase observed in CE in rats of 7 days of age may also be related to neurogenesis, since it has been reported that $\mathrm{CE}$ neurogenesis persists for up to a week after birth (Sotelo 2004). However, we also found an increase of L1 in CE of 60-day-old animals; therefore, L1 mobilization may not be limited to neuronal precursor cells. Differently, L1 content in CO tissues was increased $(p<0.05)$ in rats of 7 days of age but no statistically reliable differences were found in rats of 21 and 60 days of age, as compared to $\mathrm{H}$ tissues (Fig. 1a). CO is a neurogenic zone of the rat brain but neurogenesis in the rat postnatal cortex is negligible, occurring only in small numbers of CO cells after birth (Mehler and Gokhan 1999). Thus, the observed differences in L1 content between $\mathrm{OB}$ and $\mathrm{CE}$ on the one hand and $\mathrm{CO}$ on the other might be due to a significantly larger precursor cell pool in $\mathrm{OB}$ and $\mathrm{CE}$, as compared to $\mathrm{CO}$.
To verify whether L1 content changes during postnatal development, we compared data regarding different days of age within each single tissue (Fig. 1b). Results indicate that L1 quantity in tissues at 60 days of age was significantly higher than that in tissues at 7 days of age (Fig. 1b). Therefore, L1 activity is not completely suppressed even in the non-brain tissue. Apparent activation of retrotransposition has been reported during normal aging in various mouse tissues (De Cecco et al. 2013a; De Cecco et al. 2013b); our observations suggest that it can also occur in the tissues of young individuals.

To assess the accuracy of the results, multiplex TaqMan qPCR assays were carried out for all samples analyzing the 5' UTR L1 sequences. We made this choice because most retrotransposition events produce $5^{\prime}$ truncated elements; therefore, 5' UTR probes could have not detected all the occurred retrotransposition events but only those rare events
Fig. 3 Data from multiplex qPCR assays analyzing ORF2-2/5' UTR. Values were standardized such that the lowest value of all the experiments (heart tissue from a 7-day-old rat) was normalized to 1.0. Means and standard errors are shown. OB, olfactory bulb; CO, cortex; $\mathrm{CE}$, cerebellum; $\mathrm{H}$, heart. Number $(7,21$ and 60) is for days of age. Data are grouped by age group (a) and by tissue type (b). All one-way ANOVA analyses both between tissues within each age group (a) and between age groups within each tissue (b) were significant (respectively $p<0.005$ and $p<0.01$ ) except for $\mathrm{CO}$. Tukey HSD test and Bonferroni tests were applied, significant differences are shown. $(*)$ $p<0.05 ;(* *) p<0.01$ a

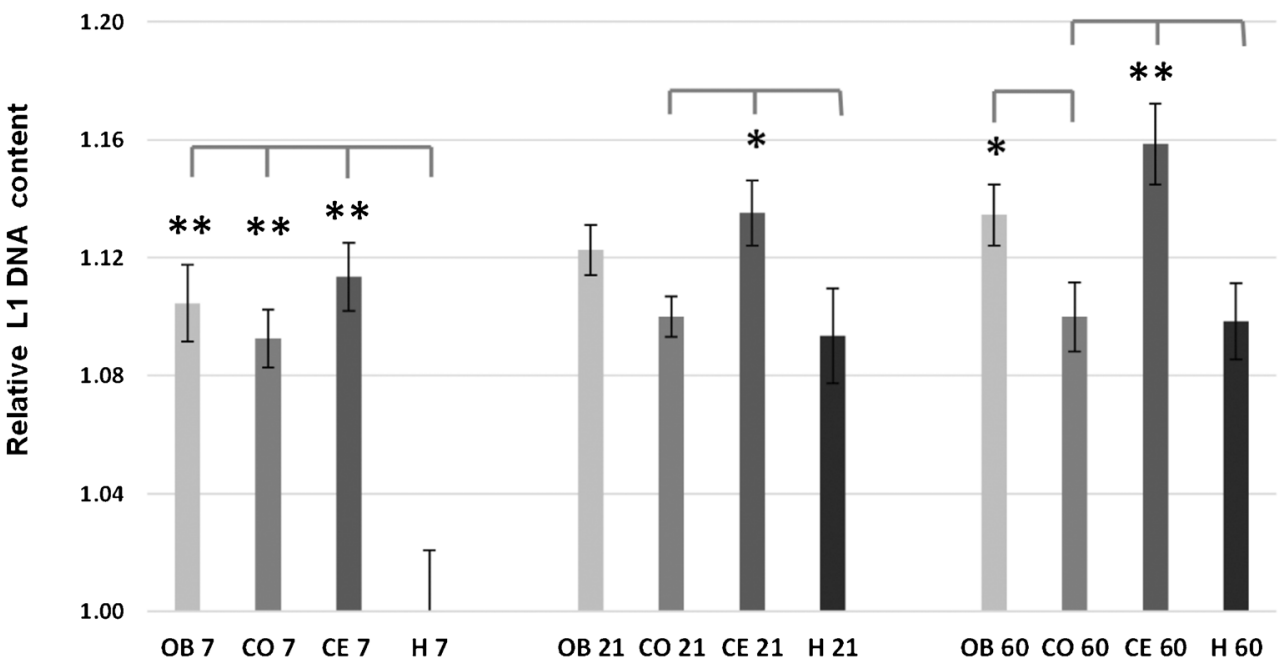

b

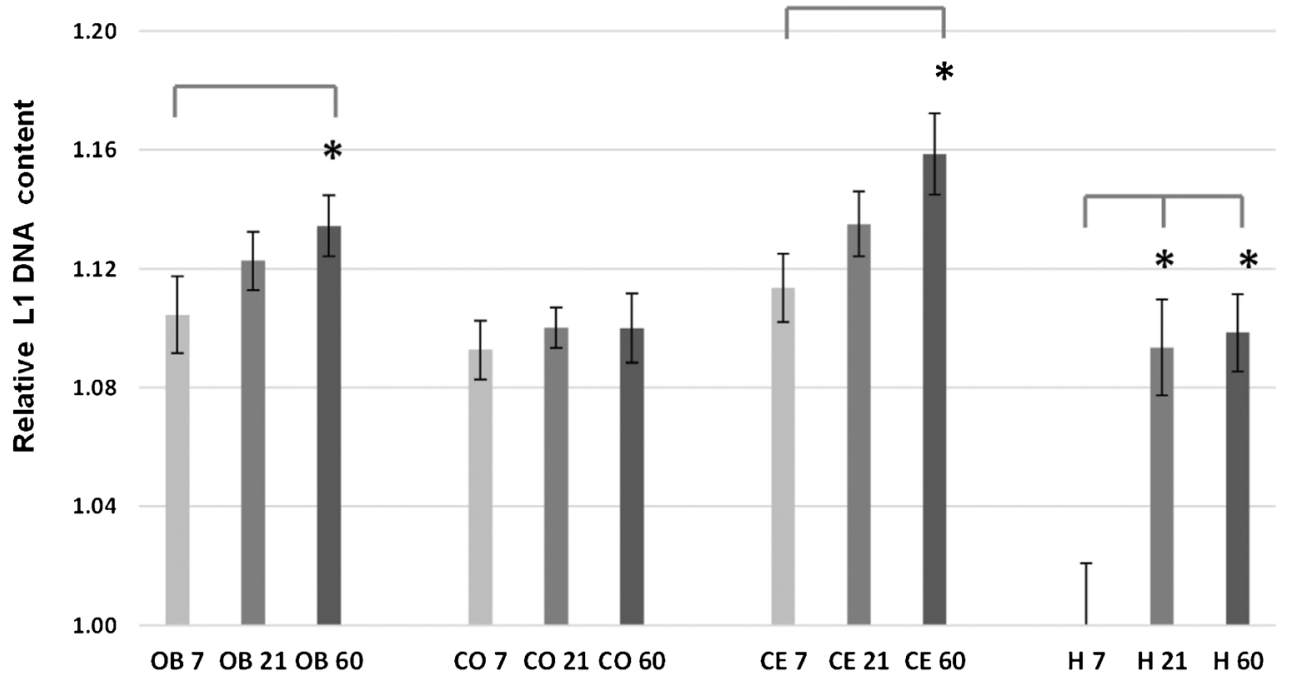


that produced full-length elements. These results are reported in Fig. 2 (individual data in Electronic Supplementary Material, Table S1). No significant change over time and tissues was found, except for a comparison between CE and $\mathrm{CO}$ at 60 days of age (Fig. 2a). Moreover, no significant difference was observed between different days of age within each single tissue (Fig. 2b). These results indicate that retrotransposition events occurring during postnatal development do not produce detectable L1 full-length elements but mostly, as expected, $5^{\prime}$ truncated L1 copies. To further assess this hypothesis, multiplex qPCR analysis was carried out analyzing another ORF2 probe (ORF2-2) together with 5' UTR sequences (Fig. 3; individual data in Electronic Supplementary Material, Table S1). Results were similar to those reported in Fig. 1, except for the fact that OB tissues at 21 days of age were not significantly different from heart tissues (Fig. 3a) and that $\mathrm{CO}$ tissues at 60 days of age were not significantly different from those at 7 days of age (Fig. $3 b)$. Overall, these results confirm that L1 content increase could be detected by ORF2 probes and not by $5^{\prime}$ UTR probes since retrotransposition events produced mostly $5^{\prime}$ truncated L1 copies. Therefore, 5' UTR sequences could be used as a high copy number DNA reference, as described by Coufal et al. (2009) for human L1.

We questioned whether there could be gender-based differences in the somatic L1 retrotransposition dynamic, so we determined the genotypic sex of each animal by PCR analyses (see Material and methods section). The samples showing PCR SRY product were male, whereas the samples without the PCR SRY product were female. Results from qPCR analysis regarding the detection of ORF2-1 and ORF2-2, separated by gender, are showed in Fig. 4. No significant difference was found between the genders. However, these results may be biased due to an unequal number of male and female rats in each age group. Further experiments would be necessary to clarify this point.

To our knowledge, this report is the first one to have evaluated the $\mathrm{L} 1$ content in different tissues from rats of different age. Some studies have dealt with L1 expression in rat brain and non-brain tissues (Singh and Rath 2012; Mukherjee et al. 2016) and found L1 RNA in several tissues, with heterogeneous levels and variations in individual rats. However, in the two above studies, L1 content was not determined since the focus was on the biological role of L1 RNA as long ncRNA and not on somatic L1 retrotransposition activity. We do not know the mechanisms that might be involved in the phenomena we observed. Much evidence indicates that the absence of methyl-CpG-binding protein 2 (MeCP2), which is a protein involved in global DNA methylation, may play a significant role in the increase of the L1 neuronal retrotransposition (Muotri et al. 2010). Several studies that dealt with MeCP2 expression in the rat brain showed that it varied by region and age (Cassel et al. 2004; Mullaney et al. 2004) but the MeCP2 levels that were reported do not appear comparable with our observations; therefore, other mechanisms could probably be involved. Recent studies have demonstrated that there can also be reverse transcribed L1 DNA in the cytosol (Thomas et al. 2017). It is important to point out that, in this study, overall L1 content was measured including any non-integrated L1 sequences. Therefore, we cannot exclude that some tissue differences in $\mathrm{L} 1$ content could also be due to non-integrated L1 sequences.

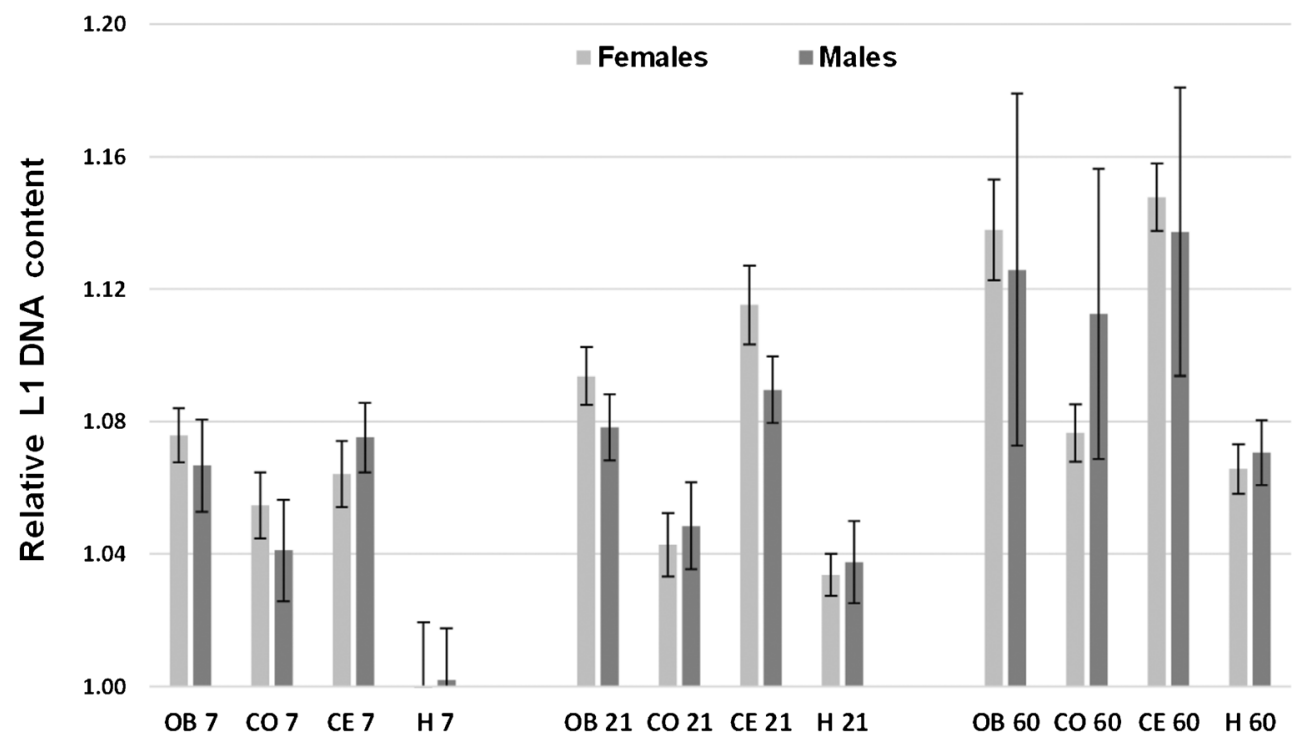

Fig. $4 \mathrm{~L} 1$ content in tissues of female $(n=11)$ and male $(n=10)$ rat of 7 , 21 and 60 days of age. Data from multiplex qPCR assays analyzing ORF2-1/5S Rib and ORF2-2/5' UTR. Means and standard errors are shown. Animals of 7 days of age: female $n=2$, male $n=5$; animals of 21 days of age: female $n=3$, male $n=2$; animals of 60 days of age:

female $n=6$, male $n=3$. OB, olfactory bulb; CO, cortex; CE, cerebellum; H, heart. Number $(7,21$ and 60$)$ is for days of age. Statistical analysis was performed by $t$ Student test. No significant difference was found between males and females 
Previously, somatic L1 retrotransposition was observed in vitro in neural progenitor cells and in vivo in human adult postmortem brain tissues. Here, we extended these findings by studying young rat tissues. Our data suggest that somatic retrotransposition occurs in rat tissue during normal development in young individuals and that the increase of L1 content is higher in brain tissue (mainly olfactory bulb and cerebellum) than in non-brain tissue. These observations raise many questions about the implication of L1 activity in postnatal development.

Funding This work was supported by RFO (Ricerca Fondamentale Orientata, Oriented Fundamental Research) grants from the University of Bologna.

\section{Compliance with ethical standards}

Conflict of interest The authors declare that they have no conflict of interest.

Ethical approval All applicable international, national and/or institutional guidelines for the care and use of animals were followed. This article does not contain any studies with human participants performed by any of the authors.

\section{References}

Abbott A (2004) Laboratory animals: the Renaissance rat. Nature 428: 464-466

Altman J (1962) Are new neurons formed in the brains of adult mammals? Science 135:1127-1128

Altman J (1969) Autoradiographic and histological studies of postnatal neurogenesis. IV. Cell proliferation and migration in the anterior forebrain, with special reference to persisting neurogenesis in the olfactory bulb. J Comp Neurol 137:433-457

Baillie JK, Barnett MW, Upton KR, Gerhardt DJ, Richmond TA, De Sapio F, Brennan PM, Rizzu P, Smith S, Fell M, Talbot RT, Gustincich S, Freeman TC, Mattick JS, Hume DA, Heutink P, Carninci P, Jeddeloh JA, Faulkner GJ (2011) Somatic retrotransposition alters the genetic landscape of the human brain. Nature 479:534-537

Boissinot S, Sookdeo A (2016) The evolution of Line-1 in vertebrates. Genome Biol Evol 8:3485-3507

Brouha B, Schustak J, Badge RM, Lutz-Prigge S, Farley AH, Moran JV, Kazazian HH Jr (2003) Hot L1s account for the bulk of retrotransposition in the human population. Proc Natl Acad Sci U S A 100:5280-5285

Bundo M, Toyoshima M, Okada Y, Akamatsu W, Ueda J, NemotoMiyauchi T, Sunaga F, Toritsuka M, Ikawa D, Kakita A, Kato M, Kasai K, Kishimoto T, Nawa H, Okano H, Yoshikawa T, Kato T, Iwamoto K (2014) Increased L1 retrotransposition in the neuronal genome in schizophrenia. Neuron 81:306-313

Cassel S, Revel MO, Kelche C, Zwiller J (2004) Expression of the methyl-CpG-binding protein $\mathrm{MeCP} 2$ in rat brain. An ontogenetic study. Neurobiol Dis 15:206-211

Cohen DR, Matarazzo V, Palmer AM, Tu Y, Jeon OH, Pevsner J, Ronnett GV (2003) Expression of MeCP2 in olfactory receptor neurons is developmentally regulated and occurs before synaptogenesis. Mol Cell Neurosci 22:417-429

Coufal NG, Garcia-Perez JL, Peng GE, Yeo GW, Mu Y, Lovci MT, Morell M, O’Shea KS, Moran JV, Gage FH (2009) L1 retrotransposition in human neural progenitor cells. Nature 460: $1127-1131$

De Cecco M, Criscione SW, Peckham EJ, Hillenmeyer S, Hamm EA, Manivannan J, Peterson AL, Kreiling JA, Neretti N, Sedivy JM (2013a) Genomes of replicatively senescent cells undergo global epigenetic changes leading to gene silencing and activation of transposable elements. Aging Cell 12:247-256

De Cecco M, Criscione SW, Peterson AL, Neretti N, Sedivy JM, Kreiling JA (2013b) Transposable elements become active and mobile in the genomes of aging mammalian somatic tissues. Aging (12):867-883

Del Re B, Giorgi G (2013) Cell-host, LINE and environment: three players in search of a balance. Mob Genet Elements 3:1-4

Del Re B, Marcantonio P, Gavoçi E, Bersani F, Giorgi G (2012) Assessing LINE-1 retrotransposition activity in neuroblastoma cells exposed to extremely low-frequency pulsed magnetic fields. Mutat Res 749:76-81

Denli AM, Narvaiza I, Kerman BE, Pena M, Benner C, Marchetto MC, Diedrich JK, Aslanian A, Ma J, Moresco JJ, Moore L, Hunter T, Saghatelian A, Gage FH (2015) Primate-specific ORF0 contributes to retrotransposon-mediated diversity. Cell 163:583-593

Erwin JA, Marchetto MC, Gage FH (2014) Mobile DNA elements in the generation of diversity and complexity in the brain. Nat Rev Neurosci 15:497-506

Evrony GD, Cai X, Lee E, Hills LB, Elhosary PC, Lehmann HS, Parker JJ, Atabay KD, Gilmore EC, Poduri A, Park PJ, Walsh CA (2012) Single-neuron sequencing analysis of L1 retrotransposition and somatic mutation in the human brain. Cell 151:483-496

Evrony GD, Lee E, Park PJ, Walsh CA (2016) Resolving rates of mutation in the brain using single-neuron genomics. elife 5. https://doi. org/10.7554/eLife. 12966

Faulkner GJ, Garcia-Perez JL (2017) L1 mosaicism in mammals: extent, effects, and evolution. Trends Genet 33:802-816. https://doi.org/10. 1016/j.tig.2017.07.004

Feng Q, Moran J, Kazazian H, Boeke JD (1996) Human L1 retrotransposon encodes a conserved endonuclease required for retrotransposition. Cell 87:905-916

Furano A (2000) The biological properties and evolutionary dynamics of mammalian LINE-1 retrotransposons. Prog Nucleic Acid Res Mol Biol 64:255-294

Gibbs RA, Weinstock GM, Metzker ML, Muzny DM, Sodergren EJ, Scherer S, Scott G, Steffen D, Worley KC, Burch PE, Okwuonu G, Hines S, Lewis L, DeRamo C, Delgado O, Dugan-Rocha S, Miner G, Morgan M, Hawes A, Gill R, Celera, Holt RA, Adams MD, Amanatides PG, Baden-Tillson H, Barnstead M, Chin S, Evans CA, Ferriera S, Fosler C, Glodek A, Gu Z, Jennings D, Kraft CL, Nguyen T, Pfannkoch CM, Sitter C, Sutton GG, Venter JC, Woodage T, Smith D, Lee HM, Gustafson E, Cahill P, Kana A, Doucette-Stamm L, Weinstock K, Fechtel K, Weiss RB, Dunn DM, Green ED, Blakesley RW, Bouffard GG, De Jong PJ, Osoegawa K, Zhu B, Marra M, Schein J, Bosdet I, Fjell C, Jones S, Krzywinski M, Mathewson C, Siddiqui A, Wye N, McPherson J, Zhao S, Fraser CM, Shetty J, Shatsman S, Geer K, Chen Y, Abramzon S, Nierman WC, Havlak PH, Chen R, Durbin KJ, Egan A, Ren Y, Song XZ, Li B, Liu Y, Qin X, Cawley S, Worley KC, Cooney AJ, D'Souza LM, Martin K, Wu JQ, Gonzalez-Garay ML, Jackson AR, Kalafus KJ, McLeod MP, Milosavljevic A, Virk D, Volkov A, Wheeler DA, Zhang Z, Bailey JA, Eichler EE, Tuzun E, Birney E, Mongin E, Ureta-Vidal A, Woodwark C, Zdobnov E, Bork P, Suyama M, Torrents D, Alexandersson M, Trask BJ, Young JM, Huang H, Wang H, Xing H, Daniels S, Gietzen D, Schmidt J, Stevens K, Vitt U, Wingrove J, Camara F, Mar Albà M, Abril JF, Guigo R, Smit A, Dubchak I, Rubin EM, Couronne O, Poliakov A, Hübner N, Ganten D, Goesele C, Hummel O, Kreitler T, Lee YA, Monti J, Schulz H, Zimdahl H, Himmelbauer H, Lehrach H, Jacob HJ, Bromberg S, Gullings-Handley J, Jensen-Seaman MI, Kwitek AE, Lazar J, Pasko D, Tonellato PJ, Twigger S, Ponting CP, Duarte 
JM, Rice S, Goodstadt L, Beatson SA, Emes RD, Winter EE, Webber C, Brandt P, Nyakatura G, Adetobi M, Chiaromonte F, Elnitski L, Eswara P, Hardison RC, Hou M, Kolbe D, Makova K, Miller W, Nekrutenko A, Riemer C, Schwartz S, Taylor J, Yang S, Zhang Y, Lindpaintner K, Andrews TD, Caccamo M, Clamp M, Clarke L, Curwen V, Durbin R, Eyras E, Searle SM, Cooper GM, Batzoglou S, Brudno M, Sidow A, Stone EA, Venter JC, Payseur BA, Bourque G, López-Otín C, Puente XS, Chakrabarti K, Chatterji S, Dewey C, Pachter L, Bray N, Yap VB, Caspi A, Tesler G, Pevzner PA, Haussler D, Roskin KM, Baertsch R, Clawson H, Furey TS, Hinrichs AS, Karolchik D, Kent WJ, Rosenbloom KR, Trumbower H, Weirauch M, Cooper DN, Stenson PD, Ma B, Brent M, Arumugam M, Shteynberg D, Copley RR, Taylor MS, Riethman H, Mudunuri U, Peterson J, Guyer M, Felsenfeld A, Old S, Mockrin S, Collins F (2004) Rat Genome Sequencing Project Consortium. Genome sequence of the Brown Norway rat yields insights into mammalian evolution Nature 428:493-521

Goodier JL (2016) Restricting retrotransposons: a review. Mob DNA 7: 16. https://doi.org/10.1186/s13100-016-0070-z

Guffanti G, Gaudi S, Klengel T, Fallon JH, Mangalam H, Madduri R, Rodriguez A, DeCrescenzo P, Glovienka E, Sobell J, Klengel C, Pato M, Ressler KJ, Pato C, Macciardi F (2016) LINE1 insertions as a genomic risk factor for schizophrenia: preliminary evidence from an affected family. Am J Med Genet B Neuropsychiatr Genet $171: 534-545$

Iskow RC, McCabe MT, Mills RE, Torene S, Pittard WS, Neuwald AF, Van Meir EG, Vertino PM, Devine SE (2010) Natural mutagenesis of human genomes by endogenous retrotransposons. Cell 141: $1253-1261$

Kazazian HH Jr (2004) Mobile elements: drivers of genome evolution. Science 303:1626-1632

Kirilyuk A, Tolstonog GV, Damert A, Held U, Hahn S, Löwer R, Buschmann C, Horn AV, Traub P, Schumann GG (2008) Functional endogenous LINE-1retrotransposons are expressed and mobilized in rat chloroleukemia cells. Nucleic Acids Res 36:648-665

Kurnosov AA, Ustyugova SV, Nazarov VI, Minervina AA, Komkov AY, Shugay M, Pogorelyy MV, Khodosevich KV, Mamedov IZ, Lebedev YB (2015) The evidence for increased L1 activity in the site of human adult brain neurogenesis. PLoS One 10:e117854. https://doi.org/10.1371/journal.pone.0117854

Levison SW, Young GM, Goldman JE (1999) Cycling cells in the adult rat neocortex preferentially generate oligodendroglia. J Neurosci Res 57:435-446

Li W, Prazak L, Chatterjee N, Gruninger S, Krug L, Theodorou D, Dubnau J (2013) Activation of transposable elements during aging and neuronal decline in Drosophila. Nat Neurosci 16:529-531
Liu S, Du T, Liu Z, Shen Y, Xiu J, Xu Q (2016) Inverse changes in L1 retrotransposons between blood and brain in major depressive disorder. Sci Rep 6:37530. https://doi.org/10.1038/srep37530

Macia A, Widmann TJ, Heras SR, Ayllon V, Sanchez L, BenkaddourBoumzaouad M, Muñoz-Lopez M, Rubio A, Amador-Cubero S, Blanco-Jimenez E, Garcia-Castro J, Menendez P, Ng P, Muotri AR, Goodier JL, Garcia-Perez JL (2017) Engineered LINE-1 retrotransposition in nondividing human neurons. Genome Res 27: 335-348

Mehler MF, Gokhan S (1999) Postnatal cerebral cortical multipotent progenitors: regulatory mechanisms and potential role in the development of novel neural regenerative strategies. Brain Pathol 9:515-526

Miousse IR, Chalbot MC, Lumen A, Ferguson A, Kavouras IG, Koturbash I (2015) Response of transposable elements to environmental stressors. Mutat Res Rev Mutat Res 765:19-39

Mukherjee S, Sharma D, Upadhyaya KC (2016) L1 retrotransposons are transcriptionally active in hippocampus of rat brain. Prague Med Rep 117:42-53

Mullaney BC, Johnston MV, Blue M (2004) Developmental expression of methyl-CpG binding protein 2 is dynamically regulated in the rodent brain. Neuroscience 123:939-949

Muotri AR, Chu VT, Marchetto MC, Deng W, Moran JV, Gage FH (2005) Somatic mosaicism in neuronal precursor cells mediated by L1 retrotransposition. Nature 435:903-910

Muotri AR, Marchetto MC, Coufal NG, Oefner R, Yeo G, Nakashima K, Gage FH (2010) L1 retrotransposition in neurons is modulated by MeCP2. Nature 468:443-446

Ostertag EM, Kazazian HH Jr (2001) Biology of mammalian L1 retrotransposons. Annu Rev Genet 35:501-538

Singh DK, Rath PC (2012) Long interspersed nuclear elements (LINEs) show tissue-specific, mosaic genome and methylation-unrestricted, widespread expression of noncoding RNAs in somatic tissues of the rat. RNA Biol 9:1380-1396

Sotelo C (2004) Cellular and genetic regulation of the development of the cerebellar system. Prog Neurobiol 72:295-339

Thomas CA, Tejwani L, Trujillo CA, Negraes PD, Herai RH, Mesci P, Macia A, Crow YJ, Muotri AR (2017) Modeling of TREX1dependent autoimmune disease using human stem cells highlights L1 accumulation as a source of neuroinflammation. Cell Stem Cell 21:319-331

Upton KR, Gerhardt DJ, Richardson SR, Sánchez-Luque FJ, Bodea GO, Ewing AD, Salvador-Palomeque C, van der Knaap MS, Brennan PM, Vanderver A, Faulkner GJ (2015) Ubiquitous L1 mosaicism in hippocampal neurons. Cell 161:228-239

Wagner JP, Black IB, Di Cicco-Bloom E (1999) Stimulation of neonatal and adult brain neurogenesis by subcutaneous injection of basic fibroblast growth factor. J Neurosci 19:6006-6016 